\title{
PALLIATIVE JAW-SPARING TREATMENT OF A NON-RESECTABLE CANINE ORAL FIBROSARCOMA USING COMBINATION OF ELECT- ROCHEMOTHERAPY WITH BLEOMYCIN AND IL-12 GENE ELECT- ROTRANSFER
}

\author{
Darja Pavlin ${ }^{1}$, Ana Nemec 1 , Urša Lampreht Tratar², Maja Čemazar², Andreja Brožič̌2, Gregor Serša², Nataša Tozon ${ }^{1 *}$ \\ ${ }^{1}$ Small Animal Clinic, Veterinary Faculty, University of Ljubljana, Cesta v Mestni log 47, ${ }^{2}$ Department of Experimental Oncology, Institute of Oncol- \\ ogy Ljubljana, Zaloska c. 2, ${ }^{3}$ Department of Cytopathology, Institute of Oncology Ljubljana, Zaloska c. 2, 1000 Ljubljana, Slovenia \\ ${ }^{*}$ Corresponding author, E-mail: natasa.tozon@vf.uni-lj.si
}

\begin{abstract}
A 15-year- old male castrated English setter was presented for evaluation of a rapidly growing oral mass. Patient's history was otherwise unremarkable, except of moderate proteinuria of 5 years duration. Clinical examination findings were within normal limits, except of an ulcerated lesion located at the left mandibular canine tooth, which was histologically confirmed as a high grade infiltrative fibrosarcoma with high mitotic index (61/10 HPF) and multifocal necrotic areas. The client declined full staging, so only hematological and biochemistry examinations of blood were performed, which were within normal limits. Furthermore a fine needle aspiration biopsy of regional lymph nodes was performed, which revealed reactive lymphadenopathy without signs of metastases. After declining other more invasive therapeutic procedures, the clients elected treatment with combination of electrochemotherapy and IL-12 electrogene therapy. Four consecutive treatment sessions were performed, resulting not only in complete response of the primary tumor, but also in regression of untreated distant metastases, which were diagnosed approximately one month after the initial examination. Furthermore, the percentage of circulating CD8+ cells was increased after each therapy session, indicating possible systemic induction of immune response by IL-12 gene therapy. This case shows that this type of therapy can represent an alternative type of both local and systemic treatment in selected tumor cases, where clients seek a less invasive nonsurgical treatment.
\end{abstract}

Key words: dog; fibrosarcoma; electroporation; electrochemotherapy; electrogene therepy; interleukin-12

\section{Introduction}

Malignant neoplasms of the oral cavity represent approximately $6 \%$ of all canine tumors, with fibrosarcoma (FSA) being one of the three most common malignant oral tumors in dogs (1). The most common site of presentation is gingiva, followed by lip, cheek and tongue (1). FSAs are reported to be primarily locally aggressive with a low potential for distant metastases. Gingival tumors can invade the bone and spread to the palate. Early diagnosed tumors (i.e., smaller tumors) are mostly treated by curative-intent surgery (2), which can be combined

Received: 16 July 2020

Accepted for publication: 26 August 2020 with radiotherapy in selected cases. However, oral tumors often develop unnoticed until the tumor reaches an advanced stage, when it is often inoperable without causing significant dysfunction and cosmetic changes to the animal. In such cases, different palliative therapeutic approaches may be used, depending on the sensitivity of the tumor. Outcome of any such therapy is usually short-lived, with reportedly high recurrence rates, even over $50 \%$ and short survival times (3). Wide margin surgical excision of oral FSA as a sole therapy results in mean survival time (MST) of 1224 months $(3,4)$.

Electrochemotherapy (ECT) and gene electrotransfer are techniques, where electric pulses are 
used to increase cell membrane permeability to enhance entry of the cytotoxic agents (i.e., electrochemothrapy, ECT) and plasmid DNA (i.e., gene electrotransfer or electrogene therapy, EGT) into the cells. ECT combined with EGT with plasmid encoding interleukin-12 (IL-12) has already been described for the treatment of a small number of naturally occurring spontaneous canine oral neoplasms with encouraging results $(5,6)$.

Important feature of ECT and EGT with plasmid encoding IL-12 is the elicitation of the immune response, which is believed to have systemic effects. IL-12 stimulates cytotoxic T lymphocytes, which are crucial in cancer elimination (7) as they target the tumor cells and eliminate them by the action of perforin and granzyme B (8). Perforin is involved in formation of pores on the membrane of tumor cells, thus enabling the granzyme $\mathrm{B}$ to enter the tumor cells where it causes apoptotic tumor cell death (9). Such induction of immune response can be detected using different techniques, including flow cytometry, which utilizes gating different types of peripheral blood mononuclear cells using specific antibodies.

The purpose of this case report is to describe a case of a large grade II mandibular gingival FSA in a 15-year-old dog successfully treated with ECT and EGT with plasmid encoding IL-12.
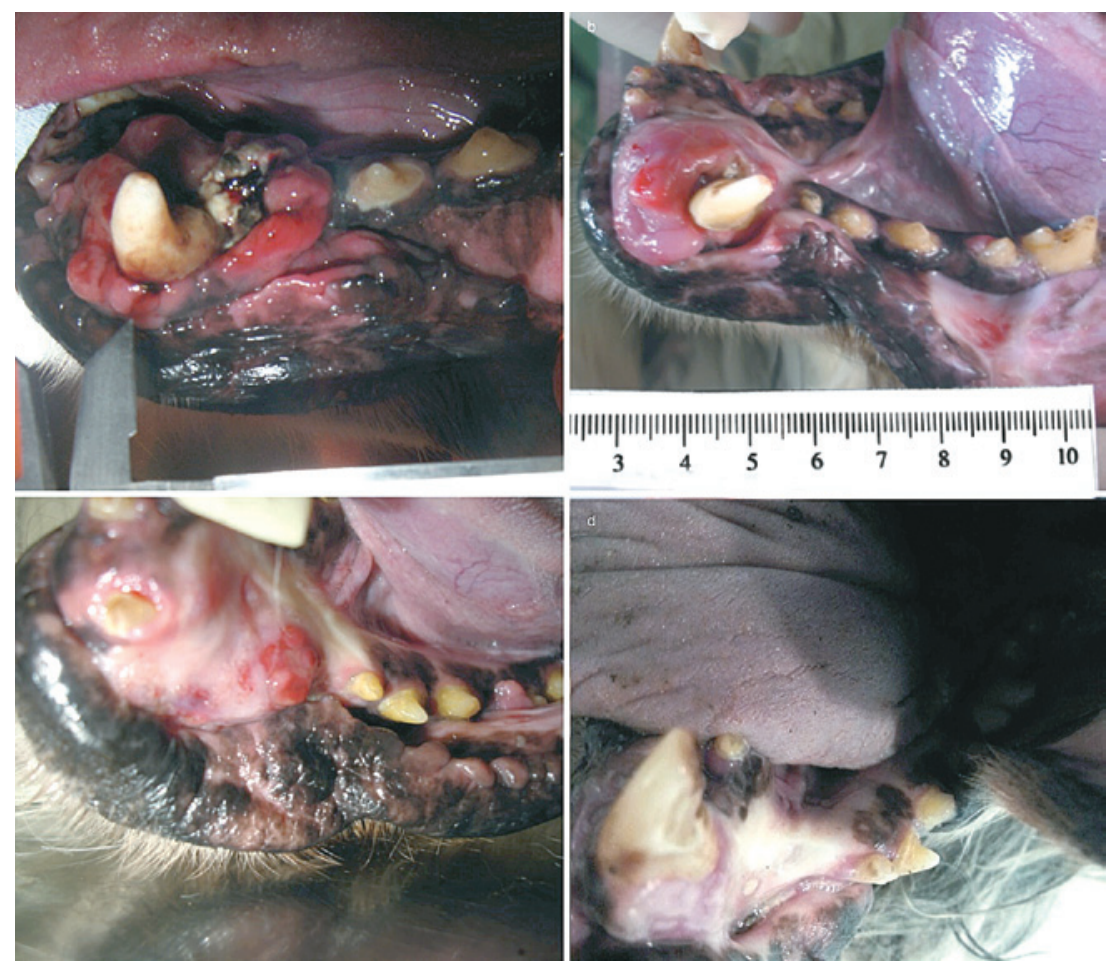

Figure 1: The figure is showing regression of the tumor mass at different time points. (A) tumor mass at the time of the first therapy. (B) clinical regression of the tumor at 4 weeks after the first therapy and before the second therapy. (C) four months after the first of the tumor therapy the size of the tumor significantlly decreased. (D) seven months after initial therapy complete regression could be seen 
irrelevant thrombocytosis (platelets $575 \times 10-9 / \mathrm{L}$, reference value $143-400 \times 10-9 / \mathrm{L}$ ).

A detailed oral examination and dental radiographs with the dog under general anesthesia were performed, revealing a $4 \mathrm{~cm} \times 3 \mathrm{~cm} \times 3 \mathrm{~cm}$ partly ulcerated proliferative mass at the left mandibular canine tooth (Figure 1). Geographic bone loss at the left mandibular incisor and canine teeth was visible on dental radiographs, and permeative pattern of bone loss in the symphyseal region suggested bony involvement of both rostral mandibles (T3b) (Figure 2). At the same time incisional biopsy was performed, and the mass was histologically confirmed as a high grade infiltrative FSA with high mitotic index (61/ 10 HPF) and multifocal necrotic areas. Fine needle aspiration biopsy of regional lymph nodes was performed, revealing reactive lymph nodes.
After discussing possible treatment options, including bilateral rostral mandibulectomy in combination with radiotherapy, the client elected ECT and EGT. During the next four months, four therapy sessions were performed (Graph 1). Each session was performed with the dog under short (approximately $30 \mathrm{~min}$ ) general anesthesia, starting with ECT using intravenous application of bleomycin (Blenoxane, Bristol-Myers, Princeton, USA; $3 \mathrm{mg} /$ $\mathrm{ml}$ ) at the dose $0.3 \mathrm{mg} / \mathrm{kg}$, followed by delivery of electric pulses with electric pulses generator Cliniporator $^{\mathrm{TM}}$ (IGEA s.r.1., Carpi, Italy). Train of 8 pulses was applied, each pulse of $100 \mu$ s duration and amplitude to electric distance ratio of 1300 $\mathrm{V} / \mathrm{cm}$ and frequency of repetition $1 \mathrm{~Hz}$, using two parallel stainless steel plate electrodes with $6 \mathrm{~mm}$ distance between them. This procedure was followed

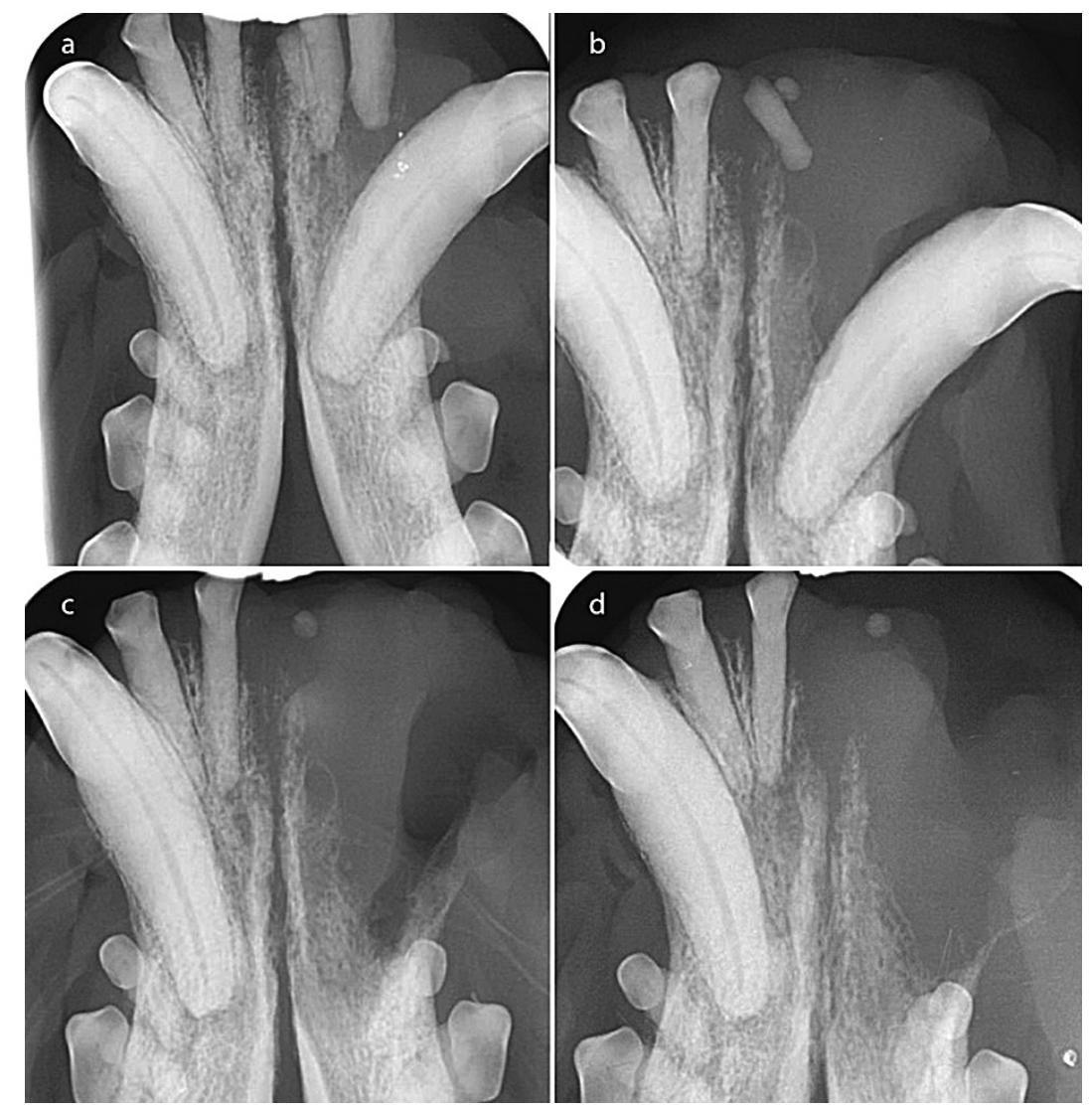

Figure 2: (A) Dental radiograph, occlusal view of the rostral mandibles at initial presentation. Geographic bone loss at the left mandibular incisor and canine teeth was visible on dental radiographs, and permeative pattern of bone loss in the symphyseal region suggested bony involvement of both rostral mandibles (T3b). Clinical assessment of radiographically abnormal (fractures or abrasion) left mandibular incisor teeth was impossible as they were embedded in the tumor mass. Right mandibular third incisor tooth is missing. (B) Dental radiograph, occlusal view of the rostral mandibles at 4 weeks. Radiographically visible severe progression of the osteolysis. Left mandibular second and third incisor teeth had exfoliated since the last visit. There is a total loss of attachment at the left mandibular first incisor tooth and near total loss of attachment at the left mandibular canine tooth, therefore these two teeth were removed (C). The round poorly mineralized structure remained, as it was hidden in the soft tissues of the tumor. (D) Dental radiograph, occlusal view of the rostral mandibles at 10 weeks. Radiographically subjectively decreased osteolysis progression 
by EGT with peritumoral application of $2 \mathrm{mg}$ of plasmid encoding canine IL-12 (pCMVcaIL-12) into the mucosa. The same generator of electric pulses was used to deliver electric pulses for gene delivery. Two sets of pulses were used, one high- and four low-voltage. High-voltage pulses consisted of $100 \mu \mathrm{s}$ duration and amplitude to electric distance ratio of $600 \mathrm{~V} / \mathrm{cm}$ and low-voltage pulses consisted of 100 $\mathrm{ms}$ and amplitude to distance ratio of $200 \mathrm{~V} / \mathrm{cm}$. Plate electrodes with $6 \mathrm{~mm}$ distance between them were used.

Tumor regression was observed 4 weeks after the first therapy (Figure 1, Graph 1), although dental radiographs revealed progression of the osteolysis, requiring removal of the left mandibular incisor and canine teeth. After the second session, subjective decrease in osteolysis progression was also noted on dental radiographs. However, one month after the first therapy a subcutaneous metastases in the intermandibular region was diagnosed by cytopathologic examination of fine needle aspirate. In the course of the next three months tumor burden steadily decreased (Graph 1) and re-check at four months after the initial therapy revealed only ongoing mild-moderate necrosis of the treated area. Client reported minimal side effects and an improved quality of life of the dog. At this time point complete remission of both intraoral tumor as well as subcutaneous metastases was reached. The dog was euthanized 8 months after the initial combined therapy due to causes unrelated to the oral tumor and at that time point the dog was without any macroscopic evidence of either oral tumor or metastases in surrounding tissue. Necropsy was declined by the client.

At different time points following each therapy $(1,2,4$ weeks and then monthly after remission was achieved), detailed bloodwork was performed, including the same hematological and biochemical parameters as at the initial staging. In addition, flow cytometry was performed on frozen whole blood collected at each visit. The lymphocytes were gated for CD45 (leukocytes), CD3 (lymphocytes T), CD4 (helper T lymphocytes) and CD8 (cytotoxic T lymphocytes) markers and the percentage of each cell population was calculated. The percentage of CD8+ cells temporarily increased after each therapy and decreased in the following weeks (Graph 1). We did not observe any change in the percentage of other cell populations. Furthermore, we used quantitative polymerase chain reaction (qPCR) with specific primers for the pCMVcaIL-12 plasmid to detect the presence of plasmid DNA in the urine, stool and oral mucosa swab samples in order to determine possible shedding of plasmid into the environment. Urine and stool samples were collected one week after each therapy and no plasmid DNA was detected in these samples. Oral mucosa swabs from the area of plasmid injection were collected immediately after the therapy and at different time points thereafter (1, 2 and 4 weeks). In the first sample maximal concentration of IL-12 plasmid detected at the site of injection was $100 \mathrm{ng} / \mathrm{mL}$ of plasmid DNA. After one week, the concentration already dropped to $0,5 \mathrm{pg} / \mathrm{mL}$ and at later time points no quantity of plasmid could be detected.

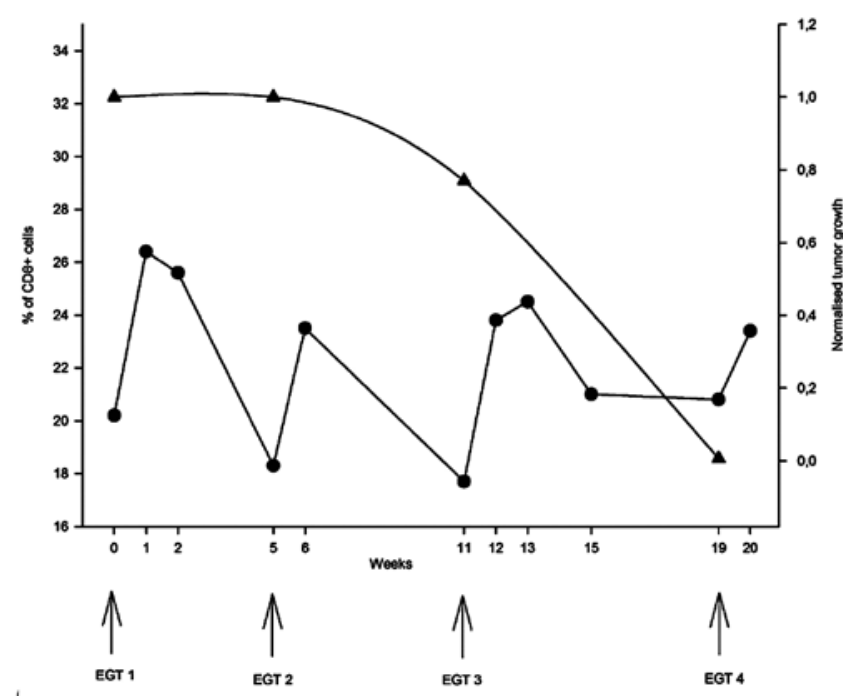

Graph 1: Percentage of CD8+ cells $(\bullet)$ detected by flow cytometry and tumor growth rate normalised on tumor size at first visit. ( $\mathbf{\Delta})$ The percentage of CD8+ cells temporarily increased after each therapy and decreased in the following weeks after EGT therapy

\section{Discussion}

In this case report we describe effective use of ECT with bleomycin and EGT with canine IL-12 in the treatment of a canine oral FSA with subcutaneous metastases, resulting in complete regression of primary treated tumor as well as untreated distant metastases, which enabled marked prolongation and improved quality of the dog's life. Oral FSA in dogs are usually fast growing neoplasms, prone to aggressive infiltrative growth. Therefore, the treatment of choice is surgical excision. However, in cases of advanced oral tumors, wide excision may cause significant cosmetic changes and, more importantly, impaired 
function in the treated animal (e.g., mandibular drift after a segmental or total mandibulectomy with glossoptosis and drooling) (2). Prolonged recovery after large surgical resections, combined with usually high costs and poor outcome (high recurrence rate due to infiltrative tumor growth), makes the owners often reluctant to elect such invasive procedures, especially in older animals, as was also the case in the presented case. Based on our previous experience with treating oral and superficial cutaneous tumors in both dogs $(10,11)$ and cats $(12)$ with either ECT or EGT or combined therapy, we offered this treatment combination as an alternative treatment option.

The dog received four therapy sessions in the course of 4 months and was euthanized 8 months after the first session due to tumor unrelated causes. At that time, there was no evidence of local tumor growth (oral cavity, intermandibular area, regional lymph nodes). Given the rapid tumor growth upon presentation (the mass approximately doubled in size in the course of one week before initiation of the treatment), the combined treatment resulted in slower progression of the tumor, with the first evidence of tumor regression 4 weeks after instituting ECT and EGT. With subsequent treatments we were able to induce complete regression of primary lesion, as well as subcutaneous metastases, which resulted in highly improved quality of the remaining life of the animal.

The pronounced cytoreductive effect of the combined treatment resulting in remission of described FSA can mainly be attributed to the ECT, since previous studies showed excellent local antitumor effect of this type of therapy, resulting in even up to $100 \%$ of complete response (CR) rates in certain human tumor types (13). In veterinary medicine, a number of studies employed ECT as an antitumor treatment, in which CR rates around 70-80\% were accomplished $(10,11,14)$. On the other hand, experience with IL12 EGT as a single treatment in veterinary patients is lacking. The only published study (15) reported less pronounced cytoreductive effect. In contrast to preclinical studies on laboratory animals in which IL12 EGT as a single therapy resulted in even $100 \%$ eradication of different tumor types $(16,17)$, study in canine mast cell tumors resulted in only $36 \%$ of $\mathrm{CR}$ rate (15).

It should be emphasized that the presented case exhibited one important distinction to other reports of ECT efficacy, namely distant effect on subcutaneous untreated metastases, which, according to the current knowledge, cannot be attributed to any antitumor effect of ECT. Although it is known, that ECT causes tumor antigen shedding into surrounding tissue and blood due to ECTinduced immunogenic cell death, this is considered inadequate for prevention of the growth of distant tumors, thus resulting in antitumor effect only at local level $(18,19,20)$. Therefore the distant effect of the combined therapy in our case can be attributed to immunotherapeutic effects of the procedure. It was already established, both on preclinical level as well as human clinical study, that IL-12 EGT exhibits antitumor effect on distant untreated tumors, distant metastases and even elicits longterm resistance to regrowth of tumors $(17,21)$. Similar distant effect on lymph node metastases was also seen in other studies, employing $I L$-12 EGT with or without ECT component $(5,15,22)$.

Immunological response to therapy was followed by flow cytometry, measuring different population of $\mathrm{T}$ lymphocytes. It was shown that dogs with tumors have decreased percentage of circulating CD8+ cells in comparison with healthy dogs (23). In our case the percentage of circulating CD8+ cells was increased after each session, which lasted up to 2 weeks. Therefore, the fluctuation of CD8+ cells in blood could serve as a guideline for timing repetition of the therapeutic procedure. In other studies, CD8+ cells were measured only in tumors, and the results showed the correlation between the increase of these cells in the tumor and better response of these tumors to the treatment in comparison to tumors without the increased infiltration of CD8+ cells $(24,25)$. It is proposed that intratumoral cytotoxic $\mathrm{T}$ lymophocytes migrate into the circulation reaching distant metastases where they can exert their immunological mediated tumor cell death (20). Therefore, the systemic increase of CD8+ lymphocytes could have abscopal effect on distant metastases, which was observed in our case. Therefore, the increase of CD8+ cells in blood could serve also as a predictive factor for the abscopal effect of the therapy.

One of the most important aspects of any gene therapy is environmental safety of the procedure. Namely, therapeutic plasmid contains antibiotic resistance gene, which can be horizontally transferred into commensal bacteria present on either treated patient's skin or in gastrointestinal tract when treating oral tumors (26). To our best knowledge, only our research group addressed this aspect of safety of IL-12 EGT in clinical setting (11). In the presented case, persistence of plasmid DNA was 
monitored, at the site of injection (mucosa) as well as in the feces and urine. Similar to the larger study (11), majority of the plasmid in oral mucosa swabs was detected immediately after application, with abrupt decline of its quantity in the first week and complete disappearance in the course of the second week after the procedure. Furthermore, no plasmid was detected in feces and urine, further confirming the results of our previous study (11), that the IL-12 plasmid cannot be horizontally transferred into the culturable bacteria from the patients, therefore the possibility of any environmental shedding of antibiotic resistance gene is negligible.

\section{Conclusion}

In conclusion, the combination of ECT with bleomycin and EGT with IL-12 plasmid in the presented case of canine oral FSA exhibited very good local and systemic antitumor effect and was safe for the treated patient. Furthermore, potential for any environmental hazard of this type of gene therapy is negligible. Therefore, this treatment modality can represent an alternative type of therapy in selected cases, where clients seek a less invasive nonsurgical treatment of these tumors.

\section{Acknowledgements}

The authors acknowledge the financial support from the state budget by the Slovenian Research Agency (program no. P3-0003, P4-0053, J3-6796, J4-2546). The research was conducted in the scope of LEA EBAM (French-Slovenian European Associated Laboratory: Pulsed Electric Fields Applications in Biology and Medicine) and is a result of networking efforts within COST TD1104 Action. The authors would like to thank dr. Tanja Švara from Veterinary faculty Ljubljana for histopathologic assessment of biopsy specimens.

\section{References}

1. Head KW. Histologic classification of the tumors of the alimentary system of domestic animals. Washington : Armed Forces Institute of Pathology, American Registry of Pathology, World Health Organization, 2003. (International Classification of Tumors of Domestic Animals, $2^{\text {nd }}$ ser., Vol. 10)

2. Lommer MJ, Verstraete FJM. Principals of oral oncologic surgery. In: Verstraete FJM, Lommer MJ, eds. Oral and maxillofacial surgery in dogs and cats.
Edinburgh : Saunders Elsevier, 2012: 423-30.

3. Frazier SA, Johns SM, Ortega J, et al. Outcome in dogs with surgically resected oral fibrosarcoma (1997-2008). Vet Comp Oncol 2012; 10: 33-43.

4. Gardner H, Fidel J, Haldorson G, Dernell W, Wheeler B. Canine oral fibrosarcomas: a retrospective analysis of 65 cases (1998-2010). Vet Comp Oncol 2013; 13: 40-7.

5. Cutrera J, Torrero M, Shiomitsu K, Mauldin N, Li S. Intratumoral bleomycin and IL-12 electrochemogenetherapy for treating head and neck tumors in dogs. Methods Mol Biol 2008; 423: 319-25.

6. Cemazar M, Tamzali Y, Sersa G, et al. Electrochemotherapy in veterinary oncology. J Vet Intern Med 2008; 22: 826-31.

7. Mehrotra PT, Wu D, Crim JA, Mostowski HS, Siegel JP. Effects of IL-12 on the generation of cytotoxic activity in human CD8+ T lymphocytes. J Immunol 1993; 151: 2444-52.

8. Maher J, Davies ET. Targeting cytotoxic T lymphocytes for cancer immunotherapy. $\mathrm{Br} \mathrm{J}$ Cancer 2004; 91: 817-21.

9. Trapani JA, Smyth MJ. Functional significance of the perforin/granzyme cell death pathway. Nat Rev Immunol 2002; 2: 735-47.

10. Kodre V, Cemazar M, Pecar J_Sersa G, Cor A, Tozon N. Electrochemotherapy compared to surgery for treatment of canine mast cell tumours. In Vivo 2009; 23: 55-62.

11. Cemazar M, Ambrozic Avgustin J, Pavlin D, et al. Efficacy and safety of electrochemotherapy combined with peritumoral IL-12 gene electrotransfer of canine mast cell tumours. Vet Comp Oncol 2017; 15(2): 641-54. doi: 10.1111/vco.12208.

12. Tozon N, Pavlin D, Sersa G, et al. Electrochemotherapy with intravenous bleomycin injection: an observational study in superficial squamous cell carcinoma in cats. J Feline Med Surg 2014; 16: 291-9.

13. Mali B, Jarm T, Snoj M, Sersa G, Miklavcic D. Antitumor effectiveness of electrochemotherapy: a systematic review and meta-analysis. Eur J Surg Oncol 2013; 39: 4-16.

14. Spugnini EP, Azzarito T, Fais S, Fanciulli M, Baldi A. Electrochemotherapy as first line cancer treatment: Experiences from veterinary medicine in developing novel protocols. Curr Cancer Drug Targets 2015; 16: 43-52.

15. Pavlin D, Cemazar M, Cör A, Sersa G, Pogacnik A, Tozon N. Electrogene therapy with interleukin-12 in canine mast cell tumors. Radiol Oncol 2011; 45: 31-9. 
16. Lucas ML, Heller L, Coppola D, Heller R. IL12 plasmid delivery by in vivo electroporation for the successful treatment of established subcutaneous B16.F10 melanoma. Mol Ther 2002; 5: 668-75.

17. Pavlin D, Cemazar M, Kamensek U, Tozon N, Pogačnik A, Serša G. Local and systemic antitumor effect of intratumoral and peritumoral IL-12 electrogene therapy on murine sarcoma. Cancer Biol Ther 2009; 8: 2114-22.

18. Campana LG, Mocellin S, Basso M, et al. Bleomycin-based electrochemotherapy: clinical outcome from a single institution's experience with 52 patients. Ann Surg Oncol 2009; 16: 191-9.

19. Calvet CY, Famin D, André FM, et al. Electrochemotherapy with bleomycin induces hallmarks of immunogenic cell death in murine colon cancer cells. Oncoimmunology 2014; 3: e28131. doi: 10.4161/onci.28131

20. Sersa G, Teissie J, Cemazar M, et al. Electrochemotherapy of tumors as in situ vaccination boosted by immunogene electrotransfer. Cancer Immunol Immunother 2015; 64: 1315-27.

21. Daud AI, DeConti RC, Andrews S, et al. Phase
I trial of interleukin-12 plasmid electroporation in patients with metastatic melanoma. J Clin Oncol 2008; 26: 5896-903.

22. Cutrera J, King G, Jones P, et al. Safe and effective treatment of spontaneous neoplasms with interleukin 12 electro-chemo-gene therapy. J Cell Mol Med 2015; 19: 664-75.

23. O'Neill K, Guth A, Biller B, Elmslie R, Dow $\mathrm{S}$. Changes in regulatory $\mathrm{T}$ cells in dogs with cancer and associations with tumor type. J Vet Intern Med 2009; 23: 875-81.

24. Fridman WH, Pagès F, Sautès-Fridman C, Galon L. The immune contexture in human tumours: impact on clinical outcome. Nat Rev Cancer 2012; 12: 298-306.

25. Giraldo NA, Becht E, Remark R, Damotte D, Sautès-Fridman C, Fridman WH. The immune contexture of primary and metastatic human tumours. Curr Opin Immunol 2014; 27: 8-15.

26. Oliveira PH, Mairhofer J. Marker-free plasmids for biotechnological applications: implications and perspectives. Trends Biotechnol 2013; 31: 539-47.

\title{
PALIATIVNO ZDRAVLJENJE NERESEKTABILNEGA FIBROSARKOMA SPODNJE ČELJUSTI PRI PSU S KOMBINACIJO ELEKTROKEMOTERAPIJE Z BLEOMICINOM IN GENSKEGA ELEKTRO- PRENOSA IL-12
}

\author{
D. Pavlin, A. Nemec, U. Lampreht Tratar, M. Čemazar, A. Brožič, G. Serša, N. Tozon
}

\begin{abstract}
Izvleček: Petnajstleni kastrirani angleški seter je bil na našo kliniko sprejet z namenom pregleda hitro rastoče novotvorbe v ustni votlini. Pes ni imel pomembnejših sočasnih bolezni, razen zmerne proteinurije zadnjih pet let. Fizikalni pregled ni pokazal nikakršnih odstopanj z izjemo ulcerirane novotvorbe na področju levega mandibularnega grabilca. Histološka diagnoza novotvorbe je bila infiltrativni fibrosarkom visoke stopnje z visokim mitotičnim indeksom (61/10 v polju visoke povečave) in multifokaInimi nekrotičnimi področji. Skrbnik psa je zavrnil popolno določitev stadija bolezni, zato smo izvedli le osnovne hematološke in biokemijske preisakve, ki niso pokazale pomembnejših odstopanj. Izvedli smo tudi tankoligelno biopsijo regionalnih bezgavk, ki je pokazala reaktivno limfadenopatijo brez znakov prisotnosti zasevkov. Po predstavitvi vseh možnosti zdravljenja se je lastnik odločil za zdravljenje s kombinacijo elektrokemoterapije in genskega elektroprenosa IL-12. Izvedli smo štiri zaporedne cikluse kombinirane terapije, s katero smo dosegli ne le popolni odgovor primarnega tumorja, pač pa tudi regresijo nezdravljenih oddaljenih podkožnih metastaz, ki so se pojavile približno mesec dni po začetku terapije. Poleg tega smo po vsaki terapiji ugotovili povečan delež cirkulirajočih CD8+ celic, kar lahko nakazuje na to, da je genska terapija z IL-12 sprožila sistemski imunski odziv. Predstavljeni primer kaže, da lahko kombinacija elektrokemoterapije in genskega elektroprenosa IL-12 predstavlja alternativno obliko tako lokalnega kot sistemskega zdravljenja določenih novotvorb, zlasti v primerih, ko skrbnikživali želi manj invazivne terapevtske postopke.
\end{abstract}

Ključne besede: pes; fibrosarkom; elektroporacija; elektrokemoterapija, genski eletroprenos; interlevkin-12 